Pain R. Embodying intimate war: a reply to Sjoberg, Massaro and

Bernazzoli. Political Geography 2015, 44, 82-83.

DOI link

https://doi.org/10.1016/j.polgeo.2014.09.012

ePrints link

http://eprint.ncl.ac.uk/244198

Date deposited

$23 / 03 / 2018$

Copyright

(c) 2015. This manuscript version is made available under the CC-BY-NC-ND 4.0 license

Licence

This work is licensed under a

Creative Commons Attribution-NonCommercial-NoDerivatives 4.0 International licence

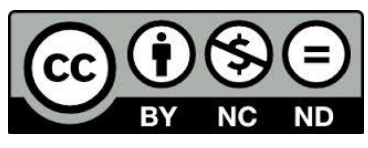




\section{Embodying intimate war: a reply to Sjoberg, Massaro and Bernazzoli}

Rachel Pain

I greatly appreciate the thoughtful engagements in the three responses. Each reader picks up and runs with the idea of intimate war, extending both the conceptualisation and its potential application to new areas. I will return to these. First, given that there is space to address only a handful of the many points made, I take a cut through those that coalesce in different ways around gendered bodies. Writing this in July 2014, the violent conflict in Palestine is at the forefront of my mind.

Intimate war is a term, as the responses suggest, that may be applied to other sorts of violence beyond domestic; wherever violence is intimately deployed and experienced, and embedded in and productive of socio-political oppression. In an effort to be clear what it is not, my account at points reiterated a binary of scale (Bernazzoli is right to sound a note of caution) but, I hope, moved us beyond to dismantle and rethink the analytical separation between different violences. The two mainstays of my argument were that the intimate is foundational to the international, both rotating as a single complex (Pain and Staeheli forthcoming); and that as such, violence in intimate war works through emotional and psychological reaches as well as physical violence. These are often less familiar dimensions of domestic violence in particular.

Sjoberg then asks, what of bodies? Theorizing embodiment in war has a valuable place (see Hyndman 2003; Fluri 2010), but my apparent eschewing of the corporeal here was deliberate. Most importantly, the account of the two women's experiences did not dwell for long on the bodily aspects of violence precisely to bring to light the lesser known emotional and psychological strategies and effects of abuse, and to place these in dialogue with the dynamics of other forms of violence, militarism and war. For me, the data in the paper include traumatic rather than 'sanitized' accounts of what bodies are made to experience. The 'grotesque' details of bodily harm that Sjoberg asks about have been documented elsewhere over four decades (e.g. Dobash and Dobash 1980). Such exposure was important to the feminist political project of locating intimate violence as 'as bad'. But there is still wide misunderstanding of domestic violence as largely constituting these bodily injuries, and there is a more general prioritisation of physical injury over emotional, social, economic or institutional violences. The point of intimate war is that these are very often rolled together. Indeed, the prioritising of bodily harm has had adverse effects; for example criminal justice responses commonly approach domestic violence as isolated incidents rather than long-term abuse 
that deploys a wide range of tactics to exert control. Furthermore, and always tricky to navigate as researchers, is a set of ethical concerns around representing those who are targets of abuse. We want to strike a balance between persuading the unpersuaded and protecting the traumatized, we want to portray cruelty but not in ways that make audiences switch off empathy and distance themselves from what they witness, and an over-focus on bodily injury can 'other' our subjects, dehumanising and depriving them of dignity (Skinner et al 2005). As Sjoberg notes, Kim and Jennifer are recognisable. Their intimate war is not distant or alien: it might be ours. It is the normalcy of these experiences - the incursion of abuse not as a freak occurrence, or present in lives that are in some ways deemed different or culpable, but as occupying the mundane sites and activities of everyday - that underpins what intimate war is and how it retains its dominion.

Stark (2007) documented in detail how perpetrators of domestic violence control the social and psychological lives of those they target, and we can see terrible parallels writ large in the current onslaught by Israel on Gaza. Here the visible physical violence of war that is the focus of the world's media has been accompanied by a long history that is not; of occupation and effective dependence, material deprivation and complete control over movement that horrifically intensifies (and makes more profoundly intimate) the effects of war (see Marshall forthcoming). Such tactics may sometimes look like strategies of non-violence, but they are also-violence that does great harm to bodies. A question here for intimate war, then, is reassessing what violence against bodies is.

The issue of bodies is also summoned by provocative questions from Massaro and Bernazzoli on the inclusion and representation of gendered bodies. Massaro calls for more attention to men as perpetrators and victims in intimate warfare across domestic, neighbourhood and peer group sites. She justifiably extends 'the intimate' to encompass these non-domestic social spaces for the men in the inner-city area in her research. The endemic violence experienced by some men in public and other spaces raises two questions here. First, evidence on whether these different violences are more or less frequent than abuse of sexual partners is mixed. Second, it is not clear that they all necessarily involve the overriding pattern of psychological occupation, subjugation and entrapment that defines intimate war. Nonetheless, Massaro make a persuasive case for exploring these complex violences, and importantly her work explicates the intersections of race, class, place and gender in intimate war. As she notes, the situation of men as targets of violence demands nuanced understandings of gendered violence, and this dovetails with Sjoberg's final point which suggests a framework for theorizing gender hierarchy (Sjoberg's previous work already does an excellent job). In my paper, I carefully detailed the reasons for my choice of two women as cases, but was somewhat torn in case this focus might be read as a narrow analysis of how gender works in 
violence. On the contrary, although men form a minority of victims of domestic violence and generally experience less severe physical violence and psychological effects of fear (Hester 2009), their experiences are both open to and able to enrich gendered readings. The same is true of men's experiences of war which, as Sjoberg (2013) makes clear, have been no more specifically analysed in mainstream literature than women's. Neither example weakens the argument about hypermasculinity rather than militarism being central to intimate war, as Bernazzoli notes. I agree unequivocally with Massaro that we should define male targets in to intimate war. The reality is that intimate war is a social phenomenon - violence that harms women hurts their brothers, fathers, sons, and vice versa. As in warzones, the seismologies of domestic violence send shockwaves through communities and effect social damage that endures through generations (Pain 2014b).

Binarised accounts of gendered identities, meanwhile, are often co-opted by the interests of power, as Bernazzoli points out. Her valuable intervention, centring on the discursive division of combatants from civilians in warzones, progresses analysis of intimate war. This distinction keeps gendered binaries alive, as both 'combatant' and 'civilian' are modelled on a male norm. The gendering of casualities of conflict, identified by Hyndman (2003) during the US war on terror, is sharply present too in reporting on Gaza. Within a hierarchy of 'grievable' victims (Butler 2010), women and children are massed together as innocent victims and 'true' civilians, and male Palestinians only represented as a danger (Mikdashi 2014). Yet the reality, as Massaro would indicate, is that men are diverse, and may be victims, perpetrators, or both. Here gender is used strategically to differentiate those who are a threat from those who must be protected (Kahlili 2011; see also Loyd 2009). Feminists have made related arguments about representation of 'victims' in domestic violence. People who have experienced domestic violence rarely identify with this term because it places them opposite power and erases their resistance (so it is avoided in my paper); as a discursive concept it reflects the feminization as a tool of subordination that Sjoberg highlights. Bernazzoli also opens up a revealing direction in identifying how gendered discourses of protection are replicated, exposing how the same dynamics of intimate war persist within the intimate spaces of military life. She observes how the institution of the military insisted on the 'profound irony' of segregation as a solution to sexual violence by male against female soldiers - here protection is not analytically separate to aggression, but another assertion of gendered power.

Reworking these binaries, of course, involves an endlessly messy politics. As Beranazzoli argues, we must problematise absolute categories in intimate war. And yet at times, the act of asserting categorical labels has great potency in resisting violent oppression. There is political as well as psychotherapeutic utility in labelling perpetrators, especially because abusive partners (like nation 
states) actively utilise 'discourses of innocence', relocating culpability and the production of violence onto their targets. Israel's continuing use of the label 'terror' to justify its violence against the people of Gaza loses any sense in light of its own deadly and fear-provoking actions.

All three responses raise questions that usefully push forward intimate war, and suggest potential lines of flight; from Sjoberg's themes of political economies of violence, bodies, and gender hierarchies, to Massaro's pursuit of the intimate aspects of men's lives and relations with violence, to Bernazzoli's examination of the non-combat spaces of military life. All point to a wider scope of gendered violences where scale is reconfigured. How far might intimate war travel from my example of domestic violence? Does the concept work, in diverse contexts? Does it become destabilised, or reshaped? Further analysis would most usefully begin from a focus on intimate relations, sites and structures, and be attentive to the particularities of conflict sites (Fluri 2010), carefully grounded and politically relevant. Bernazzoli's first-hand account provides a powerful instance of an embodied feminist approach, illustrating again that we and our psychic lives as employees, intimates, parents, citizens, activists as well as scholars (Askins 2009), are implicated in networks of violence in multiple ways. Taking off from the fertile ground that these three responses provide, my hope is that political geographers continue to reframe the intimate - no longer the poor cousin to more serious domains, but an immensely powerful and productive set of intersecting spaces of hegemonic oppression and of resistance.

\section{References}

Askins, K. (2009). 'That's just what I do': placing emotion in academic activism. Emotion, Society and Space, 2, 4-13.

Butler, J. (2010). Frames of war: when is life grievable? London: Verso.

Dobash, R. E. and Dobash, R. (1980). Violence against wives: the case against the patriarchy. Shepton Malet: Open Books.

Fluri, J. (2010). Bodies, bombs and barricades: geographies of conflict and civilian (in) security. Transactions of the Institute of British Geographers, 36, 280-96.

Hester, M. (2009). Who does what to whom? Gender and domestic violence perpetrators. Bristol: Report, University of Bristol in association with the Northern Rock Foundation.

Hyndman, J. (2003). Beyond either/or: a feminist analysis of September 11th. ACME, 2, 1, 1-13. 
Khalili, L. (2011). Gendered practices of counterinsurgency. Review of International Studies, 37, 4, 1471-1491.

Loyd, J. (2009). 'War is not healthy for children and other living things'. Environment and Planning D: Society and Space, 27, 3, 403-424.

Marshall, D. (forthcoming). Love stories of occupation: storytelling and the counter-geopolitics of intimacy. Area

Mikdashi, M. (2014). Can Palestinian men be victims? Gendering Israel's war on Gaza. Jadaliyya, 23 July 2014. http://www.jadaliyya.com/pages/index/18644/can-palestinian-men-be-victimsgendering-israels-w (accessed 29 July 2014).

Pain, R. (2014a). Everyday terrorism: connecting domestic violence and global terrorism. Progress in Human Geography, 38, 4, 531-50.

Pain, R. (2014b). Seismologies of emotion: fear and activism during domestic violence. Social and Cultural Geography, 15, 2, 127-50.

Pain, R. and Staeheli, L. (forthcoming). intimacy-geopolitics and violence. Area Sjoberg L (2013). Gendering global conflict: toward a feminist theory of war. New York: Columbia University Press.

Skinner, T., Hester, M. and Malos, E. (2005). Researching gender violence: feminist methodology in action. Devon: Willan Publishing, 1-22.

Stark, E. (2007). Coercive control: how men entrap women in personal life. Oxford: Oxford University Press. 